\title{
Synergy of Fresh and Accumulated Organic Matter to Bacterial Growth
}

\author{
Vinicius F. Farjalla • Claudio C. Marinho • \\ Bias M. Faria • André M. Amado • \\ Francisco de A. Esteves • Reinaldo L. Bozelli • \\ Danilo Giroldo
}

Received: 11 February 2008 / Accepted: 12 October 2008 / Published online: 5 November 2008

(C) Springer Science + Business Media, LLC 2008

\begin{abstract}
The main goal of this research was to evaluate whether the mixture of fresh labile dissolved organic matter (DOM) and accumulated refractory DOM influences bacterial production, respiration, and growth efficiency (BGE) in aquatic ecosystems. Bacterial batch cultures were set up using DOM leached from aquatic macrophytes as the fresh DOM pool and DOM accumulated from a tropical humic lagoon. Two sets of experiments were performed and bacterial growth was followed in cultures composed of each carbon substrate (first experiment) and by carbon substrates
\end{abstract}

V. F. Farjalla $(\bowtie) \cdot$ C. C. Marinho - B. M. Faria • A. M. Amado F. d. A. Esteves $\cdot$ R. L. Bozelli

Lab. Limnologia, Departamento Ecologia, Inst. de Biologia, CCS-UFRJ,

P.O. Box 68020, Rio de Janeiro, RJ 21941-590, Brazil

e-mail: farjalla@biologia.ufrj.br

V. F. Farjalla $\cdot$ F. d. A. Esteves

Núcleo em Ecologia e Desenvolvimento Sustentável de Macaé (NUPEM/UFRJ),

Agência Correio Macaé, Centro, Macaé, P.O. Box 119331,

Rio de Janeiro, Brazil

\section{B. M. Faria}

Centro de Pesquisa e Desenvolvimento (CENPES),

PETROBRAS,

Ilha do Fundão,

Rio de Janeiro, RJ 21949-900, Brazil

D. Giroldo

Departamento de Ciências Morfo-Biológicas, Fundação Universidade Federal do Rio Grande, Av. Itália, km 8, Vila Carreios, P.O. Box 676, Rio Grande, RS, Brazil

A. M. Amado

Programa de Pós-Graduação em Ecologia, UFRJ (PPGE-UFRJ), Rio de Janeiro, Brazil combined (second experiment), with and without the addition of nitrogen and phosphorus. In both experiments, bacterial production, respiration, and BGE were always higher in cultures with $\mathrm{N}$ and $\mathrm{P}$ additions, indicating a consistent inorganic nutrient limitation. Bacterial production, respiration, and BGE were higher in cultures set up with leachate DOM than in cultures set up with humic DOM, indicating that the quality of the organic matter pool influenced the bacterial growth. Bacterial production and respiration were higher in the mixture of substrates (second experiment) than expected by bacterial production and respiration in single substrate cultures (first experiment). We suggest that the differences in the concentration of some compounds between DOM sources, the co-metabolism on carbon compound decomposition, and the higher diversity of molecules possibly support a greater bacterial diversity which might explain the higher bacterial growth observed. Finally, our results indicate that the mixture of fresh labile and accumulated refractory DOM that naturally occurs in aquatic ecosystems could accelerate the bacterial growth and bacterial DOM removal.

\section{Introduction}

Dissolved organic matter (DOM) is one of the major pools of organic carbon on the planet. There is more carbon in the dissolved organic form in the oceans than fixed in all terrestrial plants and marine organisms combined [21]. Planktonic bacteria incorporate DOM for cell growth and energy supply. The use of DOM for bacterial production and respiration is denoted by the bacterial growth efficiency (BGE) which is defined as bacterial production/(bacterial production+bacterial respiration). Several factors influence the DOM use for bacterial production and respiration, but 
the inorganic nutrient concentration and the DOM composition seem to have a major impact $[9,11,29,30]$.

Phosphorus availability is usually the main limiting factor for bacterial secondary production in freshwater ecosystems. For instance, a consistent phosphorus limitation to bacterial production was observed in Swedish humic lakes [25], Amazonian floodplain lakes [15, 42], tropical coastal lagoons [14], and some North American ponds [8, 41]. By regulating bacterial production, phosphorus availability has a major impact on the fate of incorporated DOM into bacterial cell and oligotrophic freshwater ecosystems usually present low BGE [44]. Jansson et al. [25] proposed that DOM is allocated to bacterial biomass in high phosphorus conditions (low substrate CP ratio) as well as to bacterial respiration in low phosphorus conditions (high $\mathrm{CP}$ ratio). However, the inorganic nutrient availability usually co-variates with the quality and concentration of DOM pool, which also have a strong impact on BGE, confounding the effects of each factor.

The DOM availability to pelagic bacteria is likely to be a consequence of its source, age, chemical composition, CNP stoichiometry, arrangement of the various functional groups, and its ability to complex with other chemicals [1, 24, 45]. For instance, allochthonous humic substances are usually carbon-rich and nutrient-poor organic compounds and are considered more refractory to bacterial growth, while autochthonous DOM fixed by aquatic primary producers (planktonic algae and aquatic macrophytes) is usually more labile to bacterial growth $[1,6,16]$. It has been traditionally accepted that the DOM turnover is more related to a small pool of labile and structurally simple compounds within bulk DOM than to a large pool of more refractory and structurally complex compounds, i.e., humic substances [26]. However, when adding fulvic acids to a culture medium containing lactate as the unique carbon source, de Haan [10] observed an increase in the Pseudomonas growth and this effect has been explained in terms of co-metabolism of fulvic acid and lactate by the bacteria.

According to Wetzel [51], more than $90 \%$ of lakes and lagoons are shallow and the littoral area is the main site of primary production by aquatic macrophytes. However, most of macrophyte biomass is not consumed by herbivores and enters aquatic ecosystems through the detritus food chain. The leaching process is the first step of aquatic macrophyte decomposition and the amount and composition of DOM leachated depends on the life form of aquatic macrophyte. In general, DOM leachated from aquatic macrophytes is composed mainly by low molecular weight compounds, such as sugars and carboxylic acids, particularly available for bacterial consumption $[3,13,16,18,33$, $35,36,43]$. Therefore, macrophyte leachates may be considered important sources of labile DOM to planktonic bacteria, especially in shallow aquatic ecosystems, where we hypothesize that the entrance of this labile DOM pool could enhance the bacterial uptake of accumulated refractory compounds. In this case, the possible synergism observed by de Haan [10] would be extended to an ecosystem scale, considering multiple DOM sources.

The main goal of this research was to evaluate whether the mixture of fresh labile DOM (aquatic macrophyte leachates) and accumulated refractory DOM from a humic lagoon influences the total bacterial production, respiration, and BGE. We also evaluated the effects of inorganic nutrient supply and DOM source to bacterial growth.

\section{Methods}

Study Area and the Aquatic Macrophytes

Cabiúnas lagoon is a oligohialine humic tropical coastal lagoon located at the coastal plain in the northeast of the Rio de Janeiro State, Brazil, between $22^{\circ}$ and $22^{\circ} 30^{\prime} \mathrm{S}$ and $41^{\circ} 30^{\prime}$ and $42^{\circ} \mathrm{W}$. It is a shallow lagoon (maximum depth of $4 \mathrm{~m}$ ) and its area is ca. $0.34 \mathrm{~km}^{2}$. The lagoon has a dendritic shape with several branches, what results in a great perimeter/volume ratio and a wide littoral area. Cabiúnas lagoon is extensively colonized by aquatic macrophytes, such as Typha domingensis, Eleocharis interstincta, Potamogeton stenostachys, Nymphaea ampla, and Utricularia foliosa [22]. We chose the aquatic macrophytes T. domingensis PERS. (emergent), P. stenostachys K. Schum (submerged), and N. ampla (Salisb.) DC. (floating-leaf) because these plants present the highest densities within the groups of species with different life forms at Cabiúnas lagoon. These aquatic macrophytes and the surrounding brushy vegetation ("Restinga Vegetation") are considered the main sources of DOM to this lagoon, which is, in turn, mainly composed of refractory humic substances [14]. The climate in the region is warm and humid and presents an annual mean temperature of $26.6^{\circ} \mathrm{C}$ and annual mean precipitation of $1,500 \mathrm{~mm}$.

\section{Plant Collection and the Leaching Process}

Dead leaves of $T$. domingensis and senescent leaves of $P$. stenostachys and $N$. ampla were collected from the Cabiúnas lagoon. We chose dead or senescent leaves because the leaching process is more effective on these plants than on actively growing ones. The plant samples were washed in tap water, dried at $40^{\circ} \mathrm{C}$, and stocked until the beginning of the experiment. Each sample was leached in sterile Milli-Q water in the darkness at approximately $4{ }^{\circ} \mathrm{C}$ for $48 \mathrm{~h}$. The leaching process was not sterile; however, bacterial densities achieved less than $2 \times 10^{6}$ bacteria $\mathrm{L}^{-1}$, which we assumed to have a low impact on the amount and 
quality of the DOM leached. The leachates were filtered through $0.7 \mu \mathrm{m}$ filters $(\mathrm{GF} / \mathrm{F}$, Whatman) and were diluted to a stock concentration of $10 \mathrm{mM} \mathrm{C}$. The concentrations of dissolved nitrogen (DN), dissolved phosphorus (DP), carbohydrates, tannins, and proteins were analyzed in each leachate.

\section{Experimental Design}

Two experiments were performed to evaluate: (1) the bacterial growth in the DOM leached from each aquatic macrophyte and in a water sample from the Cabiúnas lagoon separately (single cultures) and (2) the bacterial growth in a water sample from the Cabiúnas lagoon mixed with each leachate (mixture cultures). One treatment with $\mathrm{N}$ and $\mathrm{P}$ additions (final concentrations of $50 \mu \mathrm{M} \mathrm{N}$, $\mathrm{NH}_{4} \mathrm{NO}_{3}$, and $5 \mu \mathrm{M}$, $\mathrm{KH}_{2} \mathrm{PO}_{4}$ ) and one control without nutrient enrichments were set up for each experiment. These $\mathrm{N}$ and $\mathrm{P}$ concentrations were determined to avoid $\mathrm{N}$ or $\mathrm{P}$ limitation of bacterial growth in accordance with an $\mathrm{N}$ : P molar ratio of 10:1 as proposed by Fagerbakke et al. [12] and to previous experiments also performed in coastal lagoons [14].

A water sample was collected in acid-washed and deionized water-rinsed polyethylene flasks at Cabiúnas lagoon for both experiments. Salinity was lower than 1 ppt, despite the fact that Cabiúnas is a coastal lagoon. The water sample was kept at a constant temperature (ca. $\left.25^{\circ} \mathrm{C}\right)$ until the start of each experiment $(2 \mathrm{~h})$. The leachates were first diluted in Milli-Q water to approximate the carbon concentration of Cabiúnas lagoon (ca. $1 \mathrm{mM}$ ) and then filtered through a $0.2 \mu \mathrm{m}$ filter (VacuCap filters, Gelman Science) to eliminate most bacteria. Bacterial inocula were prepared by filtering a sample of water from the Cabiúnas lagoon through a $0.7 \mu \mathrm{m}$ filter $(\mathrm{GF} / \mathrm{F}$ filter, Whatman). We previously observed that $80 \%$ of bacterial cells pass through $0.7-\mu \mathrm{m}$ pore size filters (data not shown). In the first experiment (single cultures), the cultures were composed of $90 \%$ of $0.2 \mu \mathrm{m}$ filtered leachates plus $10 \%$ of bacterial inoculum or $90 \%$ of $0.2 \mu \mathrm{m}$ filtered water from the Cabiúnas lagoon plus $10 \%$ bacterial inoculum. In the second experiment (mixture cultures), water samples from Cabiúnas lagoon were previously mixed with each leachate (50\% Cabiúnas sample $1 \mathrm{mM} \mathrm{C}-50 \%$ leachate $1 \mathrm{mM} \mathrm{C}$, final concentration of $\sim 1 \mathrm{mM} \mathrm{C}$ in each culture) and the cultures were composed of $90 \%$ of $0.2 \mu \mathrm{m}$ filtered water from the Cabiúnas lagoon combined with each leachate plus $10 \%$ of bacterial inoculum.

The cultures for each experiment $(n=4)$ were poured into acid rinsed $(\mathrm{HCl} 10 \%)$, heat sterilized $\left(120^{\circ} \mathrm{C}, 1 \mathrm{~atm}\right.$ autoclavation) $200 \mathrm{~mL}$ glass flasks and $60 \mathrm{~mL}$ BOD flasks. The cultures were incubated in the dark and the temperature was kept constant throughout the experiments. The bacterial growth was followed through changes in abundance, biomass, and respiration until the stationary phase of growth. Bacterial abundance was sampled at $0,24,48,72,96$, and $120 \mathrm{~h}$ of growth in the $200 \mathrm{~mL}$ glass flasks, while bacterial respiration was sampled at 0,72 , and $96 \mathrm{~h}$ of growth in the $60 \mathrm{~mL}$ BOD flasks. Bacterial respiration was estimated by the increase in dissolved inorganic carbon (DIC) concentration. Each BOD flask had its volume completed with sterile Milli-Q water after each measurement of bacterial respiration to avoid headspace. We had previously observed that this practice has minor impact on the DIC concentration (data not shown). Bacterial biomass was assessed by a bacterial abundance/bacterial biomass conversion factor of 35 fg C cell ${ }^{-1}$ proposed by Theil-Nielsen and Søndergaard [48] for bacterial growth in batch cultures. Finally, we also estimated BGE at the end of bacterial exponential growth in the cultures, in which bacterial production was calculated from the increase in bacterial biomass during exponential growth, and bacterial respiration was calculated from the increase in DIC concentration during exponential growth [47].

We calculated the expected bacterial production, respiration, and $\mathrm{BGE}$ in the mixture of plant leachates and Cabiúnas water based on the measurements in the plant leachates and Cabiúnas water separately (first experiment). For instance, $\mathrm{BP}_{\mathrm{Exp}}=\left(\mathrm{BP}_{\text {Leach }}+\mathrm{BP}_{\mathrm{Cab}}\right) / 2$, in which $\mathrm{BP}_{\mathrm{Exp}}$ is the expected bacterial production in the mixture of substrates, $\mathrm{BP}_{\text {Leach }}$ is the observed bacterial production in a single leachate culture, and $\mathrm{BP}_{\mathrm{Cab}}$ is the observed bacterial production in the Cabiúnas water sample. We compared the observed bacterial production, respiration and $\mathrm{BGE}$ in the mixture of plant leachates and Cabiúnas water sample (second experiment) to the expected ones. The differences between the expected and the observed values were considered to be synergic effects of the mixture of substrates on the bacterial growth (see more details in "Data Analysis" section below).

\section{Analytical Procedures}

The bacterial density was ascertained through the method proposed by Hobbie et al. [23]. Samples stained with acridine orange (final concentration of $0.005 \%$ ) were filtered through black polycarbonate filters $\left(0.2 \mu \mathrm{m}\right.$ Nuclepore $\left.{ }^{\mathbb{R}}\right)$ and the bacteria were counted using an epifluorescence microscope (Axiovert Zeiss Universal), at 1,600-fold magnification. At least 300 bacteria or 30 fields were counted per filter. The controls were prepared with sterilized water.

Dissolved organic carbon (DOC) and DIC (respiration) measurements were performed in a Shimadzu TOC-5000 carbon analyzer. The total dissolved carbon is measured as $\mathrm{CO}_{2}$, through high temperature oxidation with a platinum catalyzer. DOC is estimated by deducting the DIC from the 
total carbon. DIC was measured after sample acidification, as $\mathrm{CO}_{2}$, in an infrared sensor. At least three measurements of DOC and DIC were made for each sample and the coefficient of variation $(\mathrm{CV})$ was always less than $2 \%$. Dissolved nitrogen $(\mathrm{DN}=$ dissolved organic nitrogen + inorganic forms) concentrations were measured by digestion at $320^{\circ} \mathrm{C}$ and distillation according to Mackereth et al. [34]. Dissolved phosphorus $\left(\mathrm{DP}=\right.$ dissolved organic phosphorus $+\mathrm{PO}_{4}{ }^{-3}$ ) was analyzed by autoclaving the water samples and subsequent formation of phosphorus molybdate [19]. The concentrations of proteins were obtained after the addition of Coomassie brilliant blue G-250 and determination of the absorbance at $595 \mathrm{~nm}$ [4]. The concentrations of tannins were ascertained by the Folin reaction and determination of the absorbance at $700 \mathrm{~nm}$ [37].

The polymeric carbohydrates were analyzed, after hydrolysis, through high performance liquid chromatography coupled to pulse amperometric detection (PAD-HPLC) [20]. The PAD-HPLC analyses were performed on a Dionex $^{\mathrm{TM}}$ DX500. A PA-10 (Dionex ${ }^{\mathrm{TM}}$ ) anion-exchange analytical column $(4 \times 250 \mathrm{~mm})$, fitted with a corresponding guard column $(4 \times 50 \mathrm{~mm})$, was used to separate the monosaccharides. The monosaccharides analyzed were fucose, rhamnose, arabinose, galactose, glucose, mannose/ xylose, and fructose. $\mathrm{NaOH}(18 \mathrm{mM}$ and $200 \mathrm{mM})$ solutions were used for separation of the carbohydrates. All samples were desalted on BioRad ${ }^{\mathrm{TM}}$ ionic exchange resin (AG2X8-anion exchange and AG50W-cation exchange).

\section{Data Analysis}

Data analyses were performed with GraphPad Prism 5.01 software and a maximum probability level of $\alpha=0.05$ was used throughout to determine statistical significance. Differences in maximal bacterial abundances, BGE, and accumulated bacterial production and respiration among treatments were analyzed with analysis of variance (ANOVA) and $t$ tests. Comparison between controls and respective NP treatments indicates the significance of inorganic nutrient supply. Comparison among different carbon sources (single leachates, Cabiúnas water sample and mixtures) indicates the significance of DOM source. Combinations of DOM source and inorganic nutrient supply were examined to test whether bacteria growth was different from the expected from the factors in isolation (two-way ANOVA).

We compared the observed bacterial production, respiration and $\mathrm{BGE}$ in the mixtures of substrates to that expected based on the measurements in the plant leachates and Cabiúnas water separately using an unpaired $t$ test. If the response in the mixture of substrates exceeds the expected response, we can conclude that the substrates are interacting synergistically, a situation known as nontransgressive overyielding [32]. However, this test does not allow differentiation between two possible mechanisms (selection mechanism, in which bacteria would select one carbon source or substrate, or complementary mechanism, in which bacteria have complementary uptake of carbon sources and substrates), because we did not evaluate the bacterial consumption of specific carbon substrates from each carbon source. Therefore, we also used a more conservative test comparing the response observed in a mixture culture with the best-performing single culture [5, 32]. A higher response in mixture cultures indicates transgressive overyielding and can be interpreted as evidence of complementary mechanism.

\section{Results}

Effects of Inorganic Nutrient Supply and DOM Source on Bacterial Growth

The DOC concentration varied from 0.92 (in Typha domingensis and Potamogeton stenostachys leachates) to $0.97 \mathrm{mM}$ C (in Nymphaea ampla leachate). The N. ampla and $P$. stenostachys leachates showed higher concentrations of DP, carbohydrates and tannins than the $T$. domingensis leachate (Table 1). The P. stenostachys leachate also showed the highest concentrations of proteins. On the other hand, the T. domingensis leachate showed the highest

Table 1 Chemical composition of aquatic macrophyte leachates (Typha domingensis, Nymphaea ampla, and Potamogeton stenostachys) and the water sample from Cabiúnas Lagoon

\begin{tabular}{lccccccc}
\hline & DOC $(\mathrm{mM} \mathrm{C})$ & $\mathrm{DN}(\mu \mathrm{M} \mathrm{N})$ & $\mathrm{DP}(\mu \mathrm{M} \mathrm{P})$ & CNP ratio & $\begin{array}{l}\text { Proteins } \\
(\% \mathrm{DOC})\end{array}$ & $\begin{array}{l}\text { Carbohydrates } \\
(\% \mathrm{DOC})\end{array}$ & $\begin{array}{l}\text { Tannins } \\
(\% \mathrm{DOC})\end{array}$ \\
\hline T. domingensis & 0.92 & 37.14 & 2.58 & $357: 14: 1$ & 29 & 20 & 1 \\
N. ampla & 0.97 & 35.00 & 5.16 & $188: 7: 1$ & 11 & 34 & 31 \\
P. stenostachys & 0.92 & 32.86 & 4.52 & $204: 7: 1$ & 34 & 3 \\
Cabiúnas Lagoon & 0.96 & 30.71 & 0.19 & $5,053: 159: 1$ & & 14 \\
\hline
\end{tabular}

$D O C$ dissolved organic carbon, $D N$ dissolved nitrogen, $D P$ dissolved phosphorus. Blanks=not analyzed 
Figure 1 Bacterial growth in a unamended (control) and b NPenriched (NP treatment) cultures set up with leachates from aquatic macrophytes or with DOM from Cabiúnas Lagoon (single cultures). $[n=4$, error bars $=\mathrm{SD}]$

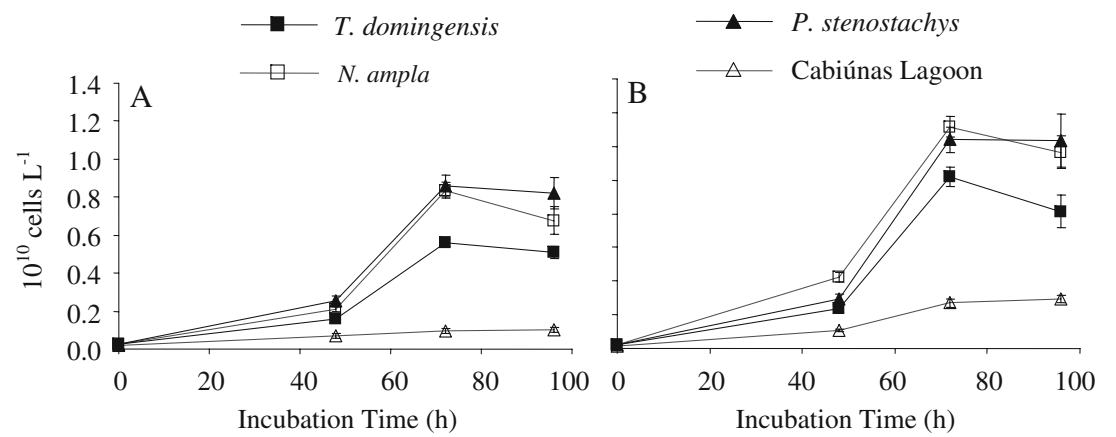

concentrations of DN, followed by $N$. ampla and $P$. stenostachys leachates (Table 1). The T. domingensis leachate presented the highest CNP ratio among all leachates. In general, Cabiúnas lagoon showed lower nutrient concentrations (except DN) and a higher CNP ratio than the plant leachates (Table 1).

All bacterial cultures (single and mixture) presented fast growth, reaching the stationary phase usually around $72 \mathrm{~h}$ (Figs. 1 and 2). Bacterial density was significantly higher in the NP treatments than in the respective controls for all plant leachates and Cabiúnas lagoon cultures $(p<$ 0.0001 , Figs. 1 and 2). The NP treatments also showed significantly higher bacterial production, bacterial respiration, and BGE than their respective controls $(p<0.05$, Fig. 3).

DOM source also affected bacterial growth. Cabiúnas lagoon water sample showed the lowest bacterial production, respiration, and BGE among single and mixture cultures $(p<0.0001$, Fig. 3). In addition, mixture cultures showed higher bacterial production and respiration than single leachate cultures $(p<0.05$, Fig. 3), except for accumulated bacterial production in mixture cultures composed by $P$. stenostachys leachate and Cabiúnas water sample which did not differ from accumulated bacterial production in single $P$. stenostachys leachate cultures. There were no differences on BGE among mixture and single leachate cultures ( $p>0.05$, Fig. 3), except for mixture cultures with $N$. ampla leachate and Cabiúnas water sample which showed higher BGE than single $N$. ampla leachate cultures $(p<0.001)$.

The DOM source, the inorganic nutrient supply, and the interaction between them affected positively the accumulated bacterial production, respiration, and BGE (Table 2). DOM source accounted from $53.0 \%$ to $78.4 \%$ of total variation of bacterial production and respiration, respectively, while, $\mathrm{N}$ and $\mathrm{P}$ additions accounted from $30.1 \%$ to $14.2 \%$ of total variation of the same parameters. The interaction between factors accounted for $3.8 \%$ to $15.7 \%$, which indicates a synergic effect between DOM source and inorganic nutrient supply (Table 2).

Synergism of Fresh and Accumulated DOM to Bacterial Growth

The observed bacterial production, respiration, and BGE in mixture cultures were significantly higher than expected calculated from the single cultures of Cabiúnas water samples and plant leachates $(p<0.001$, Fig. 3). These results per se indicate a synergism between the DOM sources to bacterial growth. Furthermore, the accumulated bacterial respiration was always higher in mixture cultures than the highest value observed in the single cultures,
Figure 2 Bacterial growth in a unamended (control) and b NPenriched (NP treatment) cultures set up with leachates of aquatic macrophytes combined with DOM from Cabiúnas Lagoon (mixture cultures). [ $n=4$, bars $=\mathrm{SD}]$

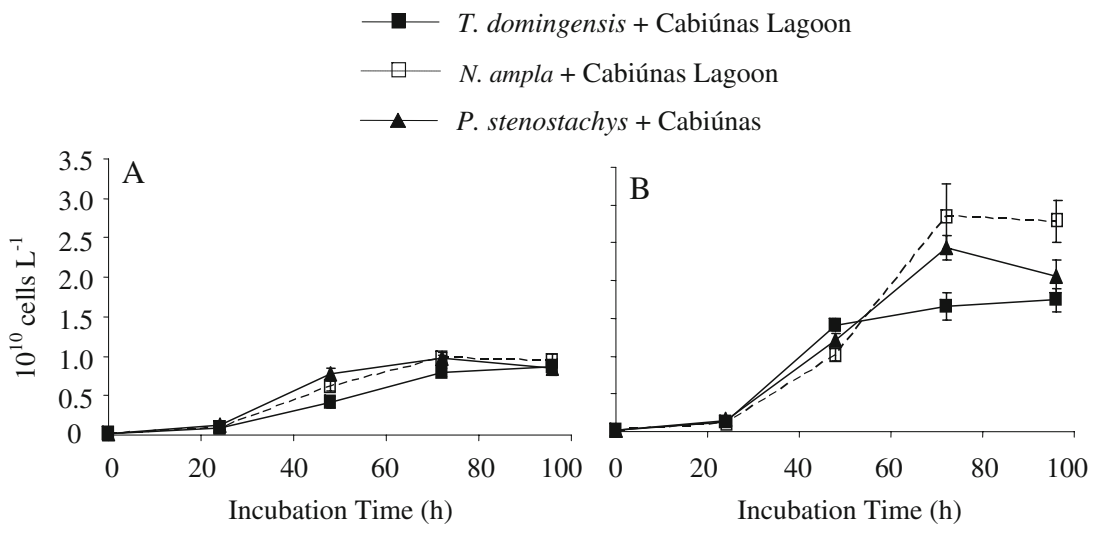



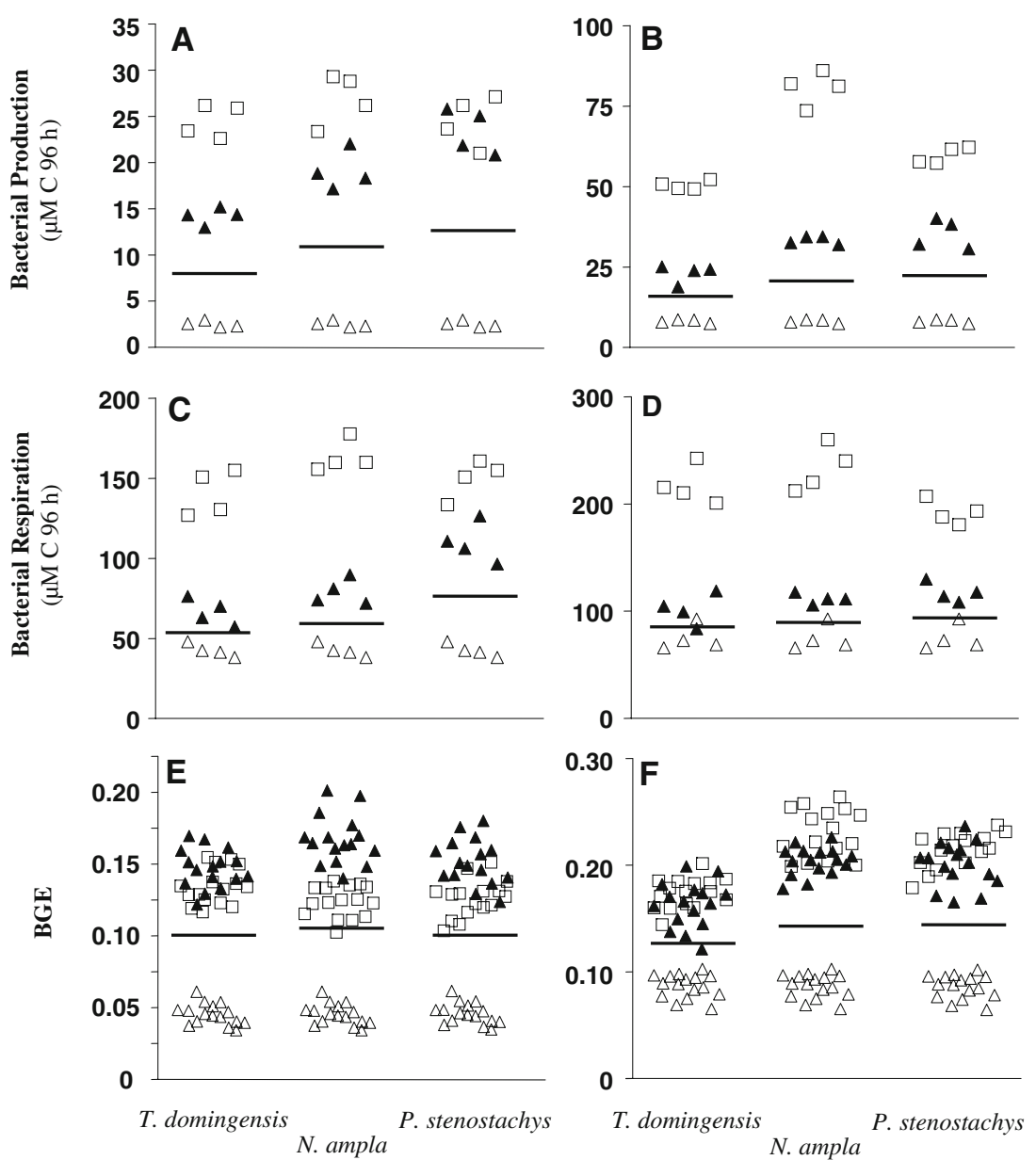

Figure 3 Accumulated bacterial production (a, b), accumulated bacterial respiration $(\mathbf{c}, \mathbf{d})$, and bacterial growth efficiency $(\mathbf{e}, \mathbf{f})$ in single substrate and mixture substrate cultures. (a), (c), and (e) refer to unamended cultures (controls) while (b), (d), and (f) refer to NPenriched cultures (NP treatments). Open triangles refer to batch cultures set up with water samples from Cabiúnas Lagoon (single cultures), dark triangles refer to batch cultures set up with macrophyte leachates (single cultures), and open squares refer to batch cultures set up with water sample from Cabiúnas Lagoon combined with macrophyte leachates (mixture cultures). We repeated the values from batch cultures set up with water samples from Cabiúnas Lagoon (open

indicating a transgressive overyielding (Table 3, Fig. 3). Only two values of accumulated bacterial production in mixture cultures (mixture between $P$. stenostachys leachate and Cabiúnas water sample, control) were lower than the highest value of accumulated bacterial production in single cultures (Table 3, Fig. 3). On the other hand, we only observed $20 \%$ of transgressive overyielding results in BGE of mixture cultures amended with inorganic nutrients in relation to the highest BGE observed in the respective single NP amended cultures, and, we did not observe any transgressive overyielding in BGE of unamended mixtures cultures (controls) in relation to the higher BGE observed in the respective single unamended cultures (Table 3, Fig. 3). triangles) in each column to facilitate comparisons. Finally, the solid lines are the expected values of bacterial production $(\mathbf{a}, \mathbf{b})$, respiration $(\mathbf{c}, \mathbf{d})$, and bacterial growth efficiency $(\mathbf{e}, \mathbf{f})$ in the mixture of plant leachates and the Cabiúnas water sample based on the measurements in the plant leachates (dark triangles) and Cabiúnas water sample (open triangles) separately. These values will be compared to the open square values (observed values in mixture cultures). Bacterial parameters were compared at the end of incubation time $[n=4$, bacterial production and respiration, and $n=16$, bacterial growth efficiency]. Note that each pair of figures (control and respective NP treatment) has different scales

Table 2 Results of two-way ANOVA to determine the effects of dissolved organic matter (DOM) source, addition of nitrogen and phosphorus, and the interaction of both factors on bacterial production, bacterial respiration, and $\mathrm{BGE}^{\mathrm{a}}$

\begin{tabular}{lccc}
\hline & $\begin{array}{c}\text { DOM } \\
\text { source }\end{array}$ & $\begin{array}{l}\text { N and P } \\
\text { additions }\end{array}$ & Interaction \\
\hline Bacterial production & $53.0^{* *}$ & $30.1^{* *}$ & $15.7^{* *}$ \\
Bacterial respiration & $78.4^{* *}$ & $14.2^{* *}$ & $3.8^{*}$ \\
BGE & $61.7^{* *}$ & $24.0^{* *}$ & $8.2^{*}$ \\
\hline
\end{tabular}

${ }^{*} p<0.01, * * p<0.001$

${ }^{a}$ Bacterial parameters were compared at the end of incubation time 
Table 3 Effects of mixtures of dissolved organic matter (DOM) sources in relation to single DOM sources on bacterial production, bacterial respiration, and $\mathrm{BGE}$

\begin{tabular}{llccr}
\hline & & Without effect & Non-transgressive effects & Transgressive effects \\
\hline Bacterial production & Control & $0(0 \%)$ & $2(16.7 \%)$ & $10(83.3 \%)$ \\
& NP treatment & $0(0 \%)$ & $0(0 \%)$ & $12(100 \%)$ \\
Bacterial respiration & Control & $0(0 \%)$ & $0(0 \%)$ & $12(100 \%)$ \\
BGE & NP treatment & $0(0 \%)$ & $0(0 \%)$ & $12(100 \%)$ \\
& Control & $1(2.1 \%)$ & $47(97.9 \%)$ & $0(0 \%)$ \\
& NP treatment & $0(0 \%)$ & $38(79.2 \%)$ & $10(20.8 \%)$ \\
\hline
\end{tabular}

Values refer to number of positive cases while values in parentheses refer to proportion of positive cases in relation to total. Both nontransgressive and transgressive effects can be considered as synergic effects of DOM sources to bacterial

\section{Discussion}

Effects of Inorganic Nutrient Supply and DOM Source on Bacterial Growth

Aquatic macrophyte leachates are considered labile substrates for bacterial growth $[6,16,17,36]$. Leachates are mainly composed of low molecular weight compounds, such as carbohydrates and amino acids, which are rapidly consumed by bacteria. On the other hand, Cabiúnas lagoon DOM pool is mainly composed of allochthonous humicrich DOM [14], which is considered more refractory to bacterial growth. Therefore, we would expect a higher bacterial production and respiration in leachate cultures than in lagoon water cultures and this pattern would be related to a greater DOM availability to bacterial growth in the formers. However, different nutrient concentrations (N and $\mathrm{P}$ ) also play a major role in regulating bacterial production and respiration. Low $\mathrm{N}$ and/or $\mathrm{P}$ concentrations or an unbalance between $\mathrm{N}$ and $\mathrm{P}$ in relation to bacterial demand indicate nutrient-limiting conditions to bacteria. For instance, phosphorus is the main limiting nutrient to bacterial production in most aquatic ecosystems, including the Cabiúnas lagoon [14]. All leachates showed higher nutrient concentrations (mainly P) and lower CNP ratios than Cabiúnas lagoon (Table 1), which would also favor a greater bacterial production and respiration in the formers (Table 2, Fig. 1). Therefore, DOM availability and nutrient concentrations are higher in aquatic macrophyte leachates than in Cabiúnas water sample, and both could limit bacterial growth at the same time. This is contradictory to the law of minimum (sensu Liebig) that predicts one factor limiting biomass production each time. This conservative view of alternative limiting factors does not fit our data (Table 2) and an alternative hypothesis based on interactive forces of DOM availability and nutrient concentrations regulating bacterial production and respiration is proposed.

The DOM fate inside the bacterial cell is of major importance for evaluating the role of planktonic bacteria in aquatic ecosystems [11]. Bacterial growth efficiency was enhanced at N- and P-enriched cultures (Table 2, Fig. 3). Besides stimulating bacterial respiration, $\mathrm{N}$ and $\mathrm{P}$ additions had a stronger effect on bacterial production (Table 2, Fig. 3) which resulted in the higher BGE values observed. During the past decades, studies focused on bacterial production regulation were far more abundant than bacterial respiration studies and the influence of $\mathrm{N}$ and $\mathrm{P}$ concentrations regulating bacterial production have been repeatedly observed [11, 25, 44]. For instance, Farjalla et al. [14] observed a 3- to 15 -fold increase of bacterial production in coastal lagoon bacterial cultures enriched with $\mathrm{N}$ and $\mathrm{P}$ while, in the same cultures, bacterial respiration increased just 1.5- to 2-fold. Jansson et al. [25] observed a consistent $\mathrm{P}$ limitation of bacterial production in an unproductive lake in Sweden, which was regulated directly the BGE.

In the present study, the impacts of DOM quality on BGE were even higher than the amount of inorganic nutrients present in cultures (Table 2). Both bacterial production and respiration were higher in leachate cultures, but bacterial production values were approximately 10 -fold higher, comparing to approximately 2 -fold higher bacterial respiration in leachate cultures than lagoon cultures (Fig. 3). All cultures were set up with similar carbon concentrations, but fresh DOM leached from aquatic macrophytes differs from accumulated humic substances found in high amounts at Cabiúnas lagoon. Qualitative aspects of natural DOM are difficult to define [31], but humic substances are relatively oxidized substrates and bacterial growth on oxidized substrates is usually energy limited [11, 50]. Therefore, humic substances are incorporated into biomass with low efficiency, despite the availability of inorganic nutrients. On the other hand, leachates presented high amounts of proteins (Table 1), and bacterial growth on amino acids usually shows high efficiencies $[6,27]$. We conclude that $\mathrm{N}$ and $\mathrm{P}$ availability and, mainly, the quality of bulk DOM regulated the BGE in this experiment, through changing bacterial production. Bacterial respiration was also enhanced at enriched cultures and fresh-leachated DOM cultures, but this increase was substantially lower than that of bacterial production. Finally, changes on BGE were more related to 
bacterial production, and bacterial respiration was more conservative among cultures, corroborating the current paradigm (for review, see [11]).

\section{Synergy of Fresh and Accumulated DOM to Bacterial} Growth

We observed a consistent synergism of fresh labile and accumulated refractory DOM to bacterial growth. The term synergism was used here referring to higher values of bacterial production and respiration observed in the mixtures of fresh labile and accumulated refractory DOM sources than expected based on combined results obtained from single DOM cultures (non-transgressive overyielding) or based on the best-performed single culture (transgressive effects) (Table 3, Fig. 3). Furthermore, the synergism among DOM sources occurred in both anabolic and catabolic bacterial metabolism, consequently enhancing the total DOM removal, but with less marked effects on BGE (Table 3, Fig. 3). Three alternative hypotheses are suggested to explain this pattern.

Differences in the concentration of some compounds among the DOM sources might be the responsible factor for the synergy of fresh and accumulated organic matter to bacterial growth in these experiments. For instance, vitamins are barely removed in aqueous extracts, such as leachates [16], but they are important to bacterial growth. Therefore, vitamins or some micronutrients usually present in natural waters could have stimulated the bacterial leachated-DOM consumption. On the other hand, $\mathrm{N}$ and especially $\mathrm{P}$ concentrations are the main limiting factors to bacterial growth in the Cabiúnas Lagoon [14]. Aquatic macrophyte leachates are $\mathrm{P}$ rich (Table 1) and this extra $\mathrm{P}$ could be used by planktonic bacteria to enhance the humic DOM scavenging in mixed cultures. Although it may have happened in controls, this hypothesis does not explain the synergism observed in NP treatments where extra nutrients were added in the cultures (Table 2).

The bacterial co-degradation of leachates and humic lagoon DOM seems to be the main process driving the synergy observed in the mixed cultures. Humic substances are a very heterogeneous carbon pool and each specific compound may be present in very small amounts in aquatic ecosystems [40]. Furthermore, each compound itself is structurally complex, formed by different chemistry functional groups. The high energy costs of specific extracellular enzyme synthesis would inhibit planktonic bacteria from metabolizing complex specific humic compounds present at very low concentrations. However, the humic compounds might be decomposed if some specific enzymes were produced to degrade other carbon compounds present at higher concentrations, such as the carbohydrates present in the leachates (Table 1). This hypothesis is supported by de Haan [10], who found a co-degradation of lactate and fulvic acids in Pseudomonas sp. cultures, and, at some scale, by Carlson et al. [7], who found an increase on consumption of semi-labile substrates by bacteria in cultures enriched with inorganic and organic nutrients. Therefore, some specific enzymes, such as $\beta$-glucosidase [38], produced by bacteria to degrade abundant leachate carbohydrates, could act on humic substances in the mixtures, resulting in higher bacterial growth observed in mixed cultures than expected in separated ones.

Finally, a greater diversity of carbon compounds in mixtures could support a greater bacterial diversity and higher metabolic rates $[7,46]$. The influence of diversity enhancing ecological processes has been observed from molecules to communities [28]. For instance, in a laboratory study, Orwin et al. [39] observed that the chemical nature and the diversity of organic compounds altered the soil microbial community and soil chemistry, which subsequently affected total respiration and cellulose decomposition. Therefore, when we mixed fresh labile and accumulated refractory DOM, the cultures might have supported bacterial diversity causing uptake of different organic compounds, which, in turn, resulted in greater production and respiration rates.

\section{Implication for DOM Metabolism in Aquatic Ecosystems}

Most aquatic ecosystems are shallow, with large littoral areas colonized by aquatic macrophytes [51]. Despite releasing large amounts of humic substances during lignin and cellulose decomposition in the sediment, senescent aquatic macrophytes and detritus release significant amounts of fresh bioavailable compounds, such as carbohydrates and amino acids [3, 43, current study]. However, most DOM in aquatic ecosystems is composed of humic substances [49]. The high complexity and diversity of humic substances hamper microbial degradation and these compounds tend to accumulate in aquatic ecosystems. Therefore, DOM bacterial metabolism in aquatic ecosystems is based on a variable input of fresh labile DOM that can be rapidly metabolized by the bacterial community and a large pool of refractory DOM, mainly composed of humic substances that, due to its low degradability and high concentrations, would cause some temporal stability in the energy flow in aquatic ecosystems [26].

In this study, we concluded that the small fresh labile DOM pool could also enhance the turnover rates of the large refractory DOM pool. Bacterial batch cultures have usually been set up using single DOM sources or natural DOM from aquatic ecosystems, limiting the analysis of interactions among sources, which naturally occurs. Therefore, the interaction between labile and refractory DOM pools would enhance bacterial production and respiration with possible 
consequences to other trophic levels and $\mathrm{CO}_{2}$ concentrations in aquatic ecosystems.

Acknowledgements VF Farjalla is particularly grateful to the FAPERJ Institution for a $\mathrm{PhD}$ scholarship. $\mathrm{AM}$ Amado and $\mathrm{CC}$ Marinho are grateful to CAPES and FAPERJ Institutions for postgraduation scholarships. Petroleo Brasileiro SA (PETROBRAS) and CNPq have kindly supported this research.

\section{References}

1. Amon RMW, Benner R (1996) Bacterial utilization of different size classes of dissolved organic matter. Limnol Oceanogr 41:4151

2. Bertisson S, Jones JB (2003) Supply of dissolved organic matter to aquatic ecosystems: autochthonous sources. In: Findlay SEG, Sinsabaugh RE (eds) Aquatic ecosystems: interactivity of dissolved organic matter. Academic, San Diego, pp 3-24

3. Boschker HMS, Dekkens EMJ, Pel R, Cappenberg TE (1995) Sources of organic carbon in the littoral of Lake Goormeer as indicated by stable carbon isotope and carbohydrate composition. Biogeochem 29:89-105

4. Bradford MMA (1976) A rapid and sensitive method for the quantification of micrograms quantities of protein utilizing the principle of protein-dye binding. Anal Biochem 72:248-254

5. Caliman A, Leal JJF, Esteves FA, Carneiro LS, Bozelli RL, Farjalla VF (2007) Functional bioturbator diversity enhances benthic-pelagic processes and properties in experimental microcosms. J N Am Benthol Soc 26:450-459

6. Carlson CA, Ducklow HW (1996) Growth of bacterioplankton and consumption of dissolved organic carbon in the Sargasso Sea. Aquat Microb Ecol 10:69-85

7. Carlson CA, Giovannoni SJ, Hansell DA, Goldberg SJ, Parsons R, Otero MP, Kevin V, Wheeler BR (2002) Effect of nutrient amendments on bacterioplankton production, community structure, and DOC utilization in the northwestern Sargasso Sea. Aquat Microb Ecol 30:19-36

8. Carlsson P, Caron DA (2001) Seasonal variation of phosphorus limitation of bacterial growth in a small lake. Limnol Oceanogr $1: 108-120$

9. Church MJ, Hutchins DA, Ducklow HW (2000) Limitation of bacterial growth by dissolved organic matter and iron in the Southern Ocean. Appl Environ Microbiol 66:455-466

10. De Haan H (1974) Effect of a fulvic acid fraction on the growth of a Pseudomonas from Tjeukemeer (The Netherlands). Freshwat Biol 4:301-310

11. del Giorgio PA, Cole JJ (1998) Bacterial growth efficiency in natural aquatic systems. Annu Rev Ecol Syst 29:503-541

12. Fagerbakke K, Heldal M, Norland S (1996) Content of carbon, nitrogen, oxygen, sulfur and phosphorus in native aquatic and cultured bacteria. Aquat Microb Ecol 10:15-27

13. Farjalla VF, Anesio AM, Bertisson S, Graneli W (2001) Photochemical reactivity of aquatic macrophyte leachates: abiotic transformations and bacterial response. Aquat Microb Ecol 24:187-195

14. Farjalla VF, Faria BM, Esteves FA (2002a) The relationship between DOC and planktonic bacteria in tropical coastal lagoons. Arch Hydrobiol 156:97-119

15. Farjalla VF, Esteves FA, Bozelli RL, Roland F (2002b) Nutrient limitation of bacterial production in clear water Amazonian ecosystems. Hydrobiologia 489:197-205

16. Farjalla VF, Azevedo DA, Esteves FA, Bozelli RL, Roland F, Enrich-Prast A (2006) Influence of hydrological pulse on bacterial growth and DOC uptake in a clear-water Amazonian lake. Microb Ecol 52:334-344

17. Findlay S, Carlough L, Crocker MT, Gill HK, Meyer JL, Smith PJ (1986) Bacterial growth on macrophytes leachate and fate of bacterial production. Limnol Oceanogr 31:1335-1341

18. Godshalk GL, Wetzel RG (1978) Decomposition of aquatic angiosperms. I. Dissolved components. Aquat Bot 5:281-300

19. Golterman HL, Clymo RS, Ohnstad MAM (1978) Methods of physical and chemical analysis of fresh water. Blackwell, Oxford, p 214

20. Gremm TJ, Kaplan LA (1997) Dissolved carbohydrates in stream water determinated by HPLC and pulse amperometric detection. Limnol Oceanogr 42:385-393

21. Hedges JI, Keil RG (1995) Sedimentary organic matter preservation: an assessment and speculative synthesis. Mar Chem 49:81115

22. Henriques RPB, Araujo DSD, Esteves FA, Franco AC (1988) Análise preliminar das comunidades de macrófitas aquáticas da Lagoa Cabiúnas, Rio de Janeiro, Brasil. Acta Limnol Brasil 2:783-802

23. Hobbie JE, Daley RJ, Jasper S (1977) Use of nuclepore filters for counting bacteria by fluorescence microscopy. Appl Environ Microbiol 33:1225-1228

24. Hopkinson CS, Vallino JJ (2005) Efficient export of carbon to the deep ocean through dissolved organic matter. Nature 433:142-145

25. Jansson M, Bergström A-K, Lymer D, Vrede K, Karlsson J (2006) Bacterioplankton growth and nutrient use efficiencies under variable organic carbon and inorganic phosphorus ratios. Microb Ecol 52:358-364

26. Jonsson A, Meili M, Bergstrom AK, Jansson M (2001) Wholelake mineralization of allochthonous and autochthonous organic carbon in a large humic lake (Ortrasket, N. Sweden). Limnol Oceanogr 46:1691-1700

27. Jørgensen NOG, Kroer N, Coffin RB, Yang X-H, Lee C (1993) Dissolved free amino acids, combined amino acids, and DNA as sources of carbon and nitrogen to marine bacteria. Mar Ecol Prog Ser 98:135-148

28. Kinzig AP, Pacala SW, Tilman D (2001) The functional consequences of biodiversity. Princeton University Press, Princeton, $\mathrm{p} 365$

29. Kritzberg ES, Cole JJ, Pace MM, Graneli W (2005) Does autochthonous primary production drive variability in bacterial metabolism and growth efficiency in lakes dominated by terrestrial C inputs. Aquat Microb Ecol 38:103-111

30. Kritzberg ES, Cole JJ, Pace MM, Graneli W (2006) Bacterial growth on allochthonous carbon in humic and nutrient-enriched lakes: results from whole-lake $\mathrm{C}-13$ addition experiments. Ecosystems 9:489-499

31. Linton JD, Stephenson RJ (1978) A preliminary study on growth yields in relation to the carbon and energy content of various organic growth substances. FEMS Microbiol Lett 3:95-98

32. Loreau M (1998) Separating chance and other effects in biodiversity experiments. Oikos 82:600-602

33. Lu XQ, Maie N, Hanna JV, Childers DL, Jaffé R (2003) Molecular characterization of dissolved organic matter in freshwater wetlands of the Florida Everglades. Water Res 37:25992606

34. Mackereth FJH, Heron J, Talling JF (1978) Water analysis: some revised methods for limnologists. Freshwater Biological Association, Cumbria Scientific Publication No. 36

35. Maie N, Jaffé R, Miyoshi T, Childers DL (2006) Quantitative and qualitative aspects of dissolved organic carbon leached from senescent plants in an oligotrophic wetland. Biogeochem 78:285314

36. Mann CJ, Wetzel RG (1996) Loading and utilization of dissolved organic carbon from emergent macrophytes. Aquat Bot 53:61-72 
37. Martin JS, Martin MM (1982) Tannin assays in ecological studies: lack of correlation between phenolics, proanthocyanidins and protein-precipitating constituents in mature foliage of six oak species. Oecologia 54:205-211

38. Münster U, De Haan H (1998) The role of microbial extracellular enzymes in the transformation of dissolved organic matter in humic lakes. In: Hessen DO, Tranvik LJ (eds) Aquatic humic substances: ecology and biogeochemistry. Springer, Berlin, pp 199-258

39. Orwin KH, Wardle DA, Greenfield LG (2006) Ecological consequences of carbon substrate identity and diversity in a laboratory study. Ecology 83:580-593

40. Perdue EM (1998) Chemical composition, structure and metal binding properties. In: Hessen DO, Tranvik LJ (eds) Aquatic humic substances: ecology and biogeochemistry. Springer, Berlin, pp 41-61

41. Reche I, Pace ML, Cole JJ (1998) Interactions of photobleaching and inorganic nutrients in determining bacterial growth on colored dissolved organic carbon. Microb Ecol 36:270-280

42. Rejas D, Muylaert K, De Meester L (2005) Nutrient limitation of bacteria and sources of nutrients supporting nutrient-limited bacterial growth in an Amazonian floodplain lake. Aquat Microb Ecol 39:57-67

43. Sala MM, Jürgens K (2004) Bacterial growth on macrophyte leachate in the presence and absence of bacterivorous protists. Arch Hydrobiol 161:371-389
44. Smith EM, Prairie YT (2004) Bacterial metabolism and growth efficiency in lakes: the importance of phosphorus availability. Limnol Oceanogr 49:137-147

45. Sun L, Perdue EM, Meyer JL, Weis J (1997) Use of elemental composition to predict bioavailability of dissolved organic matter in a Georgia river. Limnol Oceanogr 42:714-721

46. Szabó KE, Itor POB, Bertilsson S, Tranvik L, Eiler A (2007) Importance of rare and abundant populations for the structure and functional potential of freshwater bacterial communities. Aquat Microb Ecol 47:1-10

47. Søndergaard M, Theil-Nielsen J (1997) Bacterial growth efficiency in lakewater cultures. Aquat Microb Ecol 12:115122

48. Theil-Nielsen J, Søndergaard M (1998) Bacterial carbon biomass calculated from biovolumes. Arch Hydrobiol 141: 195-207

49. Thomas JD (1997) The role of dissolved organic matter, particularly free amino acids and humic substances, in freshwater ecosystems. Fresh Biol 38:1-36

50. Vallino JJ, Hopkinson CS, Hobbie JE (1996) Modeling bacterial utilization of dissolved organic matter: optimization replaces Monod growth kinetics. Limnol Oceanogr 41:15911609

51. Wetzel RG (1990) Land-water interfaces: metabolic and limnological regulators. Verh Internat Verein Limnol 24:6-24 